\title{
Factors Influencing Tourist Visit in North Sulawesi, Indonesia
}

\author{
Lisbeth Mananeke $^{1 *}$, Rizan Machmud ${ }^{2}$ \\ ${ }^{1}$ Faculty of Economics and Business, Sam Ratulangi University, Manado 95115, Indonesia \\ ${ }^{2}$ Faculty of Economics, State University of Gorontalo, Gorontalo 96128, Indonesia
}

Corresponding Author Email: lisbethmananeke@unsrat.ac.id

https://doi.org/10.18280/ijsdp.160416

Received: 27 March 2021

Accepted: 21 July 2021

\section{Keywords:}

tourism, security, tourism visit

\begin{abstract}
\end{abstract}
\section{INTRODUCTION}

Indonesia is a multicultural republic with so many ethnics, religion, culture, and languages, then makes Indonesia as a country rich with its natural resources [1]. By using the natural resources properly, there will be a potential of prosperity and welfare for the Indonesian citizens. One of many excellent potentials that could be improved is the tourism sector. From time to time, the tourism sector in Indonesia is developing and currently well-evolved [2,3]. Tourism is one of the most incredible socio-economic phenomena of the twentieth century. It singly started from an action "enjoyed by only a small group of relatively well-off people" during the first half of the last century, it gradually became a mass popular during the post- World War II, particularly from the 1970s and onwards1 It now reaches wider scale and larger numbers of people throughout the world, and is a source of employment for a significant segment of the labor force. Tourism is capable of prop up conservation through local \& private funds, communal conservancies, and contributions to public protected areas, but only under some circumstances, and with associated environmental costs [4]. Tourism as "a temporary short-term movement of people to destinations outside the place where they normally live and work and includes the activities they indulge in at the destination as well as all facilities and services especially created to meet their needs [5].

The development of tourism requires cooperation from the government, the private sector and the community because tourism is a multimedia industry that involves the intervention of all parties [6]. Currently, tourism is a priority for Indonesia in order to increase state revenues outside oil, gas and taxes; thus, Indonesia is one of the developing countries that promotes tourism to increase the number of foreign tourist arrivals [7]. Indonesia could develop its potential from the aspect of tourism so that it was able to overcome the problems of strengthening the economy through foreign exchange or regional income. The increasing welfare or economy for the community from tourism activities can be seen from the decline of the number of unemployed in the tourist destination so that tourism is also considered as a catalyst for development and as an agent of development as well as a major driver in development [8].

Management of the tourism industry that is well managed by all parties can ultimately prosper the community if it is developed to the maximum [8]. Opening tourist destinations will create economic activities around tourist destinations that absorb labour in the formal and informal sectors [9]. However, the classic problem often emerges regarding the limited funds to develop potential tourism destinations that are relatively large with a fairly long return [8]. Tourist destinations generally require supporting facilities, such as access and amenities, which are sometimes not a priority for local governments so it needs support not only from the government but also from the private sector and the community [10].

The enhancement and development of tourism sector have a significant and strong role in domestic development program for the area surrounding the tourism site because it can act as main industrial sector, or can be called prime sector which is the sector that could improve the local area's economic condition especially for the new-development areas. In order to avoid becoming an undeveloped area, the usage of tourism sector as potential owned by the local area for its own development and the development of regional income. Tourism sector is one of the alternatives for its regional income as well as foreign exchange. Even for first-world countries, it is crucial to develop the tourism sector. Related to 
this, in Undang-Undang Republik Indonesia No. 9 Tahun 1990 stated that Tourism has an important role in expanding and leveling the employment rate and field, improve regional development, enlarging national income in order to increase social welfare and prosperity as well as nourishing the sense of nationality, and strengthen nationality identification while tighten up the good relationship with the other countries [11, $12]$.

The development of tourism sector is also improving and speed up economic growth [13]. Tourism activities creates demand, either consumption or investment that in return will create the activity of producing goods or services. While doing their touring, tourists will make a purchase, so it will automatically create demand (Tourism Final Demand) of goods and services. Next, the Tourism Final Demand indirectly creates demand on capital goods and raw materials (Investment Derived Demand) to create production in order to fulfill tourists demand on these goods and services. In order to fulfill tourist's demand, it is needed to invest in transportation and communication, hospitality business, and other accommodation industry, handicrafts industry, consumer product industry, services industry, restaurants [14]. The advancement of tourism industry in certain area is well depended on the number of tourists visit, so that it must be supported by improving the utilization of tourist sites so that the tourism industry will develop well [15].

Indonesia has an excellent natural sight sites and are very suitable for the development of tourism industry in Indonesia. In order of that, it is necessary to improve the number of tourists visit by developing any existing tourism sites. Tourism sites that have factors that determine the tourism activities such as infrastructure, accessibility, and etc., determine the number of tourists visit and also the tourist satisfaction that visited several tourism sites in North Sulawesi. The development of culture and tourism is explained on Rencana Pembangunan Jangka Menengah Daerah (RPJMD) of North Sulawesi. The development of culture and tourism is an integral part that continuously between the stages and the process of development that already been done with the desired condition and or will be reached in the intermediate or long term [16].

North Sulawesi Province has a big potential in tourism, especially natural tourist destination, maritime tourist destination, and historical tourist destination [17]. Along the years, the growth of tourist visitation either global or local tourists is increasing. In this case, there should be a development in order to increase tourist visitation by development the existing tourism destinations. Tourism destination that has crucial factors in tourism activities are having service quality, natural tourism destination, etc. are crucial in determining the level of tourism visitation and tourism satisfaction $[18,19]$. Based on the data collected from Tourism Department of North Sulawesi, it is showed that in North Sulawesi Province, there's a growing in tourism visit with highest increase in the latest four years which is six times bigger of $600 \%$ bigger within the range of 2015 (18.600) to April 2019 (30.500) [20].

Based on these crucial considerations, research is made to determine the factors that influence the level of tourism visit on several tourism destination in North Sulawesi Province.

\section{METHOD}

The research method used in this research is quantitative method using numeric data and focusing on research process of result measurement objectively using statistical analysis.

\subsection{Population, sample, and sampling technique}

Population in this study is people or tourist that visited any tourism attraction in North Sulawesi Province. The sampling technique used in this research is proportional random sampling. Proportional random sampling technique make the most possible suitable sample provided. Based on these considerations, it is accepted that the sample of 450 is the practically accepted number of samples by using the structural equation modeling. The following calculation can be used to determine the sample:

$$
n=\frac{Z^{2}}{4(m o e)^{2}}=\frac{1.96^{2}}{4(0,1)^{2}} n=96,04
$$

$\mathrm{N}=$ Number of Sample

$\mathrm{Z}=$ Level of Normal Distribution of Significant Level $5 \%$ (1.96)

Moe $=$ Margin of Error, which is the maximum toleration level of error in sampling, which is $10 \%$

This research conducted by spreading the questionnaire to 100 respondents that proving the sample size used in this research are more than the minimum or required respondents. The sample size of 100 respondents is the visitors of the tourism attraction in North Sulawesi Province consists of three areas: Tomohon City, Minahasa Regency, and North Minahasa Regency.

\subsection{Data and source of data}

The type of data in this research are primary data and secondary data, that conducted by data collection method of questionnaire or the official data provided by the official competent agency. In the implementation, the primary data obtained from tourists and community that already visited to the tourism attraction in North Sulawesi Province based on the questionnaire and the secondary data obtained from Tourism and Cultural Department of North Sulawesi.

\subsection{Data collection method}

Data collection method used in this research are questionnaire and interview. Interview is used in order to obtain the starting data and used to get a more detailed data in its relationship with the object and the subject of this research. Questionnaire used to examine the clarification aspects including purpose of research study conducted, response strategy, communication approaches and structure. The application of these method is a structured (opened) or unstructured (closed) to the respondents.

Data analysis

Data analysis consisted of 3 parts, namely: 1) Descriptive for respondent characteristics data, 2) Pearson Correlation test, 3) Multiple linear regression with a significance level of $p$ $<0.05$ and using the SPSS program. 


\section{RESULTS \& DISCUSSION}

\subsection{Respondents characteristic}

The sample in this research is 100 respondents. Data collection method is by using questionnaires. The respondents are qualified by sex, age, education, and occupation. Table 1 show that the male respondent are 55 respondents or contributed 55\% from the whole sample, and the rest of them are female, with 45 respondents, or contributed $45 \%$ from the total sample. In this research, male tourist is the most dominant visitors and choosing the tourism sites in North Minahasa Regency because the male tourists are preferring the challenging touring activities. The respondents in age between 21-30 years old are 70 respondents or contributed $70 \%$ of the total respondents. The respondents in age between 21-30 years old are also the respondents that prefer the challenging touring activities and the refreshing touring activities.

Table 1. Respondents characteristic

\begin{tabular}{c|c|c|c}
\hline \multicolumn{2}{c|}{ Characteristic } & n & \% \\
\hline \multirow{2}{*}{ Sex } & Male & 55 & 55.0 \\
& Female & 45 & 45.0 \\
\hline \multirow{3}{*}{ Education } & Junior High School & 30 & 30.0 \\
& Senior High School & 68 & 68.0 \\
& Undergraduate & 2 & 2.0 \\
\hline \multirow{3}{*}{ Age } & Under 20 years-old & 3 & 3.0 \\
& $21-30$ years old & 70 & 70.0 \\
& $31-40$ years old & 27 & 27.0 \\
\hline
\end{tabular}

The respondents in this research are mostly the respondents with the education level of Senior High School with 68 respondents or contributed $68 \%$ of the total respondents. The respondents are respondents with the education level of Senior High School because in this level of education, the respondents have the tendency of high curiosity, so that they are dominating the suitable respondents. Meanwhile the lowest rate of respondents are the respondents with the level education of Associate Degree because they still related to their educational activities.

\subsection{Validity and reliability testing}

Validity of a test means a test or an instrument is measuring accurately what it is supposed to measure. By comparing the correlation index of Pearson product moment correlation coefficient to test the validity of the variable, with the level of significant to $5 \%$ it is possible to determine whether the research instrument is valid or not. Data processed showed that correlation index is higher than 0.5 and below the level of 5\% significant so data is considered valid (Table 2).

Reliability implies that there is consistency in a test. Test is reliable when there are consistency and stability of test scores. Reliability consistency between item tested by using the popular method proposed by Cronbach, also known as Cronbach Alpha. It is showed that Cronbach Alpha is 0.891 that above the level of acceptance, which is 0.6 (Table 3), and so, research instrument is reliable. 0.891 of Cronbach Alpha is processed by questionnaire tabulation and then converted by using SPSS. With the result showed that the research instrument used is reliable.

Table 2. Correlation and significance

\begin{tabular}{|c|c|c|c|c|c|c|c|}
\hline & & $\begin{array}{c}\text { Tourism } \\
\text { Attraction }\end{array}$ & Accessibility & Facility & Promotion & Security & Tourist Visit \\
\hline $\begin{array}{c}\text { Tourism } \\
\text { Attraction }\end{array}$ & $\begin{array}{c}\text { Pearson Correlation } \\
\text { sig (2-tailed) } \\
\mathrm{N}\end{array}$ & $\begin{array}{c}1 \\
100\end{array}$ & $\begin{array}{c}678^{\prime \prime} \\
0.000 \\
100\end{array}$ & $\begin{array}{c}0.391 " \\
0.000 \\
100\end{array}$ & $\begin{array}{c}0.558 " \\
0.000 \\
100\end{array}$ & $\begin{array}{c}0.569 " \\
0.000 \\
100\end{array}$ & $\begin{array}{c}0.414 " \\
0.000 \\
100\end{array}$ \\
\hline Price & $\begin{array}{c}\text { Pearson Correlation } \\
\text { sig (2-tailed) } \\
\text { N } \\
\end{array}$ & $\begin{array}{c}0.678 * * \\
0.000 \\
100 \\
\end{array}$ & $\begin{array}{c}1 \\
100 \\
\end{array}$ & $\begin{array}{c}0.649 * * \\
0.000 \\
100 \\
\end{array}$ & $\begin{array}{c}0.627 * * \\
0.000 \\
100 \\
\end{array}$ & $\begin{array}{c}0.697 \\
0.000 \\
100 \\
\end{array}$ & $\begin{array}{c}0.482 * * \\
0.000 \\
100 \\
\end{array}$ \\
\hline Place & $\begin{array}{c}\text { Pearson Correlation } \\
\text { sig (2-tailed) } \\
\mathrm{N} \\
\end{array}$ & $\begin{array}{c}0.391 * * \\
0.000 \\
100 \\
\end{array}$ & $\begin{array}{c}0.649 * * \\
0.000 \\
100 \\
\end{array}$ & $\begin{array}{c}1 \\
100 \\
\end{array}$ & $\begin{array}{c}0.673 * * \\
0.000 \\
100 \\
\end{array}$ & $\begin{array}{c}0.680 * * \\
0.000 \\
100 \\
\end{array}$ & $\begin{array}{c}0.463 * * \\
0.000 \\
100 \\
\end{array}$ \\
\hline Promotion & $\begin{array}{c}\text { Pearson Correlation } \\
\text { sig (2-tailed) } \\
\text { N }\end{array}$ & $\begin{array}{c}0.558 * * \\
0.000 \\
100\end{array}$ & $\begin{array}{c}0.627 * * \\
0.000 \\
100\end{array}$ & $\begin{array}{c}0.673 * * \\
0.000 \\
100\end{array}$ & $\begin{array}{c}1 \\
100 \\
\end{array}$ & $\begin{array}{c}0.680 * * \\
0.000 \\
100\end{array}$ & $\begin{array}{c}0.541 * * \\
0.000 \\
100\end{array}$ \\
\hline Security & $\begin{array}{c}\text { Pearson Correlation } \\
\text { sig (2-tailed) } \\
\text { N } \\
\end{array}$ & $\begin{array}{c}0.569 * * \\
0.000 \\
100 \\
\end{array}$ & $\begin{array}{c}0.697 * * \\
0.000 \\
100 \\
\end{array}$ & $\begin{array}{c}0.680 * * \\
0.000 \\
100\end{array}$ & $\begin{array}{c}0.680 * * \\
0.000 \\
100\end{array}$ & $\begin{array}{r}1 \\
100 \\
\end{array}$ & $\begin{array}{c}0.535 * * \\
0.000 \\
100\end{array}$ \\
\hline $\begin{array}{c}\text { Tourist } \\
\text { Visit }\end{array}$ & $\begin{array}{c}\text { Pearson Correlation } \\
\text { sig (2-tailed) } \\
\text { N } \\
\end{array}$ & $\begin{array}{c}0.414 * * \\
0.000 \\
100\end{array}$ & $\begin{array}{c}0.482 * * \\
0.000 \\
100\end{array}$ & $\begin{array}{c}0.463 * * \\
0.000 \\
100\end{array}$ & $\begin{array}{c}0.541 * * \\
0.000 \\
100\end{array}$ & $\begin{array}{c}0.535^{* *} \\
0.000 \\
100\end{array}$ & $\begin{array}{c}1 \\
100 \\
\end{array}$ \\
\hline
\end{tabular}

Table 3. Reliability test

\begin{tabular}{c|c|c}
\hline $\begin{array}{c}\text { Cronbach } \\
\text { Alpha }\end{array}$ & $\begin{array}{c}\text { Cronbach's Alpha Based } \\
\text { on Standardized items }\end{array}$ & N of Items \\
\hline 0.891 & 0.891 & 6 \\
\hline
\end{tabular}

\subsection{Multiple linear regression}

Result in Table 4 can be modified into this equation:

$\mathrm{Y}=(7.204)+0.57 \mathrm{X} 1+0.71 \mathrm{X} 2+0.48 \mathrm{X} 3+0.256 \mathrm{X} 3+0.214 \mathrm{X} 4$
Interpretation of this multiple linear regression is as follows:

- In the equation, the constant $=4.402$ showed the condition in which every independent variable is zero, the growth $(\mathrm{Y})$ as dependent variable is 7.204

- Coefficient value 0.57 means that if there's an increase of one unit of reputation (X1), there will be an increase on growth (Y) up to 0.57 with assumption that others variable is constant.

- Coefficient value 0.71 means that if there's an increase of one unit of distance (X2), there will be an increase on 
growth (Y) up to 0.71 with assumption that others variable is constant.

- Coefficient value 0.48 means that if there's an increase of one unit of distance (X3), there will be an increase on growth (Y) up to 0.48 with assumption that others variable is constant.

- Coefficient value 0.256 means that if there's an increase of one unit of distance (X4), there will be an increase on growth (Y) up to 0.256 with assumption that others variable is constant.

Coefficient value 0.214 means that if there's an increase of one unit of distance (X5), there will be an increase on growth (Y) up to 0.214 with assumption that others variable is constant.

Table 4. Multiple linear regression result

\begin{tabular}{|c|c|c|c|c|c|c|c|}
\hline \multirow{2}{*}{ Model } & \multicolumn{2}{|c|}{$\begin{array}{c}\text { Unstandardized } \\
\text { Coefficients }\end{array}$} & $\begin{array}{c}\text { Standardized } \\
\text { Coefficients }\end{array}$ & \multirow{2}{*}{$\mathrm{t}$} & \multicolumn{2}{|c|}{ Sig } & \multicolumn{2}{|c|}{ Collinearity Statistics } \\
\cline { 2 - 4 } & $\mathrm{B}$ & Std. Error & Beta & & & Tolerance & VIF \\
\hline (Constant) & 7.204 & 1.928 & & 3.736 & 0.000 & & \\
Tourist Attraction & 0.057 & 0.113 & 0.061 & 0.502 & 0.617 & 0.473 & 2.114 \\
Price & 0.071 & 0.125 & 0.081 & 0.571 & 0.569 & 0.341 & 2.935 \\
Place & 0.048 & 0.119 & 0.052 & 0.398 & 0.691 & 0.398 & 2.510 \\
Promotion & 0.256 & 0.125 & 0.265 & 2.055 & 0.043 & 0.412 & 2.427 \\
Security & 0.214 & 0.127 & 0.228 & 1.688 & 0.095 & 0.375 & 2.667 \\
\hline
\end{tabular}

Data processed showed the multicollinearity computation model, that could be seen from the VIF and Tolerance value. If the value of VIF and Tolerance is $<10$ means that the regression model is free from multicollinearity. The multicollinearity phenomenon is not happened, because the VIF value of Tourist Attraction (X1) is 2.114, VIF value of Price (X2) is 2.936, VIF value of Place (X3) is 2.510, VIF value of Promotion (X4) is 2.427, and the VIF value of Security (X5) is 2.667. These variables have VIF value $<10$, this means that there is no relation among the independent variables. It is concluded that, the assumption of no multicollinearity is fulfilled (free from multicollinearity).

Based on the data collected from 100 respondents who already visited North Sulawesi, and the hypotheses testing, this research showed that the variable Tourist Visit, Tourism Attraction, Price, Promotion, Facility, and Security simultaneously and positively influence significantly toward the research "Factors that influence the Tourist Visit in North Sulawesi". This is proved by result of this research and hypotheses testing done using linear regression test.

The result of this research showed that tourist visit influence tourist behavior dan the number of visits as seen in the result of this research based on the collection of questionnaires spread to 100 respondents which are tourism attraction, price, promotion, and security influence the number of tourists visit in North Sulawesi. Significantly, tourist visit has a high influence on tourist behavior visit. Researcher found that the factors that influence tourist visit are tourist attraction, price, facility, promotion, and security, are a strong predictor for tourist as a consideration to visit a destination. So, it is concluded that these factors are very important and affect the level and number of tourists visit in North Sulawesi Province.

\subsection{Tourist attraction factor effect}

Taken from the result of t-test conducted by researcher, tourist attraction has an influence on tourist visit level. The effect of independent variable partially could be seen from the value of $t$ that significant. Result from the $\mathrm{t}$-test showed that tourist attraction (X1) has a significant and positive coefficient. Reputation variable become an affecting and dominant variable that affecting the level of tourist visit in this research by showing as a dominant beta coefficient 502 and lowest significance level at $6.617<0.05$. This means that tourist attraction has a dominant influence.

A tourist attraction is a potential that drives the presence of tourists in a tourist destination. In order for a tourist attraction to bring in tourists, a tourist attraction must be managed professionally so that it can attract tourists to visit. Tourism potential is the attraction contained in an area to be developed into an attractive tourist object and is able to attract tourist visits to the area, and usually it has not been worked out or has not been properly managed, so it still needs to be improved or developed.

Wiyata also supported this research concluded that variable that must be noticed covers the dependent variable which is tourist visit. This result proved and showed that tourist attraction brings the level of tourist visit in North Sulawesi Province. From the t-test result conducted by researcher, tourist attraction has an influence on level of tourist visit in North Sulawesi Province. Independent variable effect partially can be seen from the value of significant $t$. Result of t-test showed that the variable tourist attraction (X1) has a positive coefficient and significant influence [21].

Tourist attraction (X1) become the dominant variable that effect on level of tourist visit in this research showed by the dominant beta coefficient 502 and lowest significance $t$ $0.617<0.05$. This means that $(\mathrm{X} 1)$ has a dominant influence. The purpose of tourist attraction is to create tourist visit and increase the level of visitation in the tourist destination in North Sulawesi Province.

Regarding this matter, researcher found that tourist destinations in North Sulawesi have a tourist attraction that determine the choice of tourist to visit because the tourist attraction that encompasses natural beauty and has their own signature.

\subsection{Price factor effect}

Based on the statistic t-test it is explained that the influence of price toward tourist visit level is positively significant coefficient. Price also becoming a second strongest variable that influence the level of tourist visit in North Sulawesi in this research. The influence of independent variable partially can be seen from the value of $t$ that significant. The result of t-test showed that Price (X2) has a positive coefficient and significant. The influence of Price (X2) to the level of tourist visit shows a high beta coefficient at 571 and the significance 
t lower at $0.569<0.05$. This means that Price $(\mathrm{X} 2)$ has a strong influence.

Price has a positive effect on visiting decisions. This shows that if there is an increase in prices, it will reduce consumer decisions to visit. Prices in this study are ticket prices, food / beverage prices offered, rental prices, and other facilities.

\subsection{Facility factor effect}

Facility factor effect on tourist visit level, based on the statistic of t-test, can explaining the influence of facility to the tourist visit level in North Sulawesi Province, has an insignificant and negative coefficient. In this research, the influence of independent variable partially can be seen from the value of $t$ that significant. The result of t-test shoed that variable Place (X3) has a negative and insignificant coefficient. The influence of Place (X3) on tourist visit level has the lowest beta coefficient at 398 and highest significance value at $0.691<0.05$. This means that Facility (X3) has a weak influence on the tourist visit level. This research showed that facility has a weak impact or even has no influence on tourist visit level in tourist destination in North Sulawesi.

Facility is a service provided by a tourist attraction to support or support the activities of tourists visiting a tourist attraction. If a tourist attraction has adequate facilities and meets service standards and can satisfy visitors, it can attract more tourists through good impressions from previous visitors. Facilities are something that is very important in the service business, therefore the existing facilities, namely the condition of the facilities, the completeness of interior and exterior designs and the cleanliness of the facilities must be considered, especially those that are closely related to what consumers feel directly.

Several things that need to be considered in the provision of facilities, in this study the facility indicators used are [22]: 1) Completeness, cleanliness, and neatness of the facilities offered are the state of the company's facilities which are equipped with the attributes that accompany them and are supported by cleanliness and tidiness when consumers use these facilities; 2) The conditions and functions of the facilities to be offered are those that are functioning properly and are not damaged; 3) The ease of using the facilities offered means that the facilities offered to consumers are familiar facilities for consumers so that consumers can use them easily; 4) Completeness of the tools used are tools used by consumers in accordance with their specifications.

\subsection{Promotion factor effect}

Based on the t-test result conducted by researcher, Promotion (X4) has an influence on tourist visit level in tourism destination in North Sulawesi. The influence of independent variable partially can be seen from the value of $t$ that significant. The result of t-test showed that Promotion (X4) has a positive and significant coefficient. Reputation variable (X4) becomes the strongest and a dominant variable affecting on the behavior of tourist visit level in this research by showing that it has the highest beta coefficient at 2.055 and lowest significance at $0.043<0.05$. This means that reputation (X4) has the strongest influence. Promotion simultaneously and partially influence tourist behavior significantly [23]. Promotion mix was advertising, sales promotion, public relations and publicity, and direct marketing influenced simultaneously the decision of tourist in visiting Agrowisata
Tenayan Raya Pekanbaru of Riau province [24].

Promotion is a special marketing variable to attract the attention of potential tourists to a particular definition and enjoy various activities designed in the industry [25]. In promotional business, it is meant to inform, persuade, and remind tourists - whether directly or indirectly - about a product or brand that is sold to prospective journalists about the offered product by telling people where to look at or where to look and where they are. the right place.

\subsection{Security factor effect}

Based on the statistical result of t-test can be explained that the influence of security on the tourist visit level in North Sulawesi Province has a positive and significant coefficient. Security becomes the second strongest variable that impact on the tourist visit level in North Sulawesi Province. In this research the influence of independent variable partially can be seen from the value of $t$ that significant. Result of t-test showed that Security (X5) has a positive and significant coefficient. The influence of Security (X5) on the tourist visit level showed a high beta coefficient at 1.688 and a lower significance of $t$ at $0.095<0.05$. This means that Security (X5) has a strong influence. Realizing the importance of safety and security factors of tourist, emerges the idea from World Tourism Organization (WTO) to provide guidance as a reference for management in every tourism industry $[16,26]$. The low level of public understanding about tourism awareness raises several factors that have implications for the inconvenience and insecurity of tourists in the tourism area of Kuta Lombok. [27].

Comfort and safety are very important conditions in the tourism industry [27]. This aspect in the last two decades has become a bigger issue and has had a huge impact on the sustainability of travel and tourism activities [28]. Threats to the comfort and safety of tourists can be influenced and caused by a variety of factors, such as terrorist acts, local conflicts, natural disasters, social behavior and infectious diseases so that it can cause a decrease in the sense of security for tourists. Comfort and safety for tourists is one of the factors that determine the decision to take a trip to a tourism destination.

\section{CONCLUSION}

Based on the result and discussion of this research, it is concluded that tourist attraction, price, promotion, and security have a significant influence on tourist visit, in which tourist attraction has a variety and uniqueness, price is considered affordable, and a proper safety and security in the sites are the appropriate choices for the tourist in doing their activities. Meanwhile, place has no significant influence on tourist visit considering the tourist sites is worth to visit as long as the previous significant factors is met.

The result of this research can be a reference for Tourism Department of North Sulawesi considering the Promotion (X4) as the strongest variable that can improve the tourist visit level in North Sulawesi Province. It is also important for Tourism Department of North Sulawesi to review the significant factors provided in this research and later implement the best alternative and supportive actions needed in order to improve the significant factors to ultimately increase tourist visitation in North Sulawesi especially visitation in tourism sites. 


\section{ACKNOWLEDGMENT}

Thank you to Tourism Department of North Sulawesi Leaders, and the Data Collection Team who were very cooperative and collaborated well so that this research could be carried out.

\section{REFERENCES}

[1] Zarbaliyev, H. (2017). Multiculturalism in globalization era: History and challenge for Indonesia. Journal of Social Studies (JSS),

13(1). https://doi.org/10.21831/jss.v13i1.16966

[2] Haryana, A. (2020). Economic and welfare impacts of Indonesia's tourism sector. Jurnal Perencanaan Pembangunan: The Indonesian Journal of Development Planning, $\quad 4(3)$ : 300-311. https://doi.org/10.36574/jpp.v4i3.127

[3] Ollivaud, P., Haxton, P. (2019). Making the most of tourism in Indonesia to promote sustainable regional development. OECD Economics Department Working Papers. https://doi.org/10.1787/c73325d9-en

[4] Buckley, R. (2012). Conservation tourism. The Encyclopaedia of Sustainable Tourism, Cab International, pp. 129-130.

[5] Roday, S., Biwal, A., Vandana, J. (2009). Tourism Operations and Management, Illustrated edition. New Delhi: Oxford University Press.

[6] Djabbari, M.H., Alwi, Suryadi. (2021). Public private partnership model in tourism development in North Toraja District. Enrichment: Journal of Management, 11(2): 378-382.

[7] Nahar, F.H., Adha, M.A., Azizurrohman, M., Ulfi, I., Karimah, H. (2019). Determinants of international tourism in Indonesia. International Tourism Demand in Indonesia: Gravity Model Approach, 12(2): 298-317. https://doi.org/10.15294/jejak.v12i2.19440

[8] Rhama, B., Setiawan, F. (2020). Asssessing public private partnership in Indonesia tourism. Policy \& Governance Review, 4(3): 197-209. https://doi.org/10.30589/pgr.v4i3.339

[9] Holik, A. (2016). Relationship of economic growth with tourism sector. JEJAK: Jurnal Ekonomi dan Kebijakan, 9(1). https://doi.org/10.15294/jejak.v9i1.7184

[10] Haddadi, M., Khodadadpoor, M. (2015). The role of public-private partnership contracts in tourism industry development. IJAREMS, 4(1): 234-244. https://doi.org/10.6007/IJAREMS/v4-i1/1628

[11] Presiden Republik Indonesia. (1990). Undang-Undang Republik Indonesia Nomor 9 Tahun 1990 Tentang Kepariwisataan. Departemen Kehutanan Republik Indonesia: https://jdih.baliprov.go.id/uploads/produkhukum/peraturan/1990/UU/uu-9-1990.pdf.

[12] Pradana, G.Y.K. (2019). Sosiologi Pariwisata. Stpbi Press, 1(1): 1-88.

[13] Manzoor, F., Wei, L., Asif, M., ul Haq, M.Z., ur Rehman, H. (2019). The contribution of sustainable tourism to economic growth and employment in Pakistan. Int $\mathbf{J}$ Environ Res Public Health, 16(19): 3785. https://doi.org/10.3390/ijerph16193785

[14] Antara, M., Sumarniasih, M.S. (2017). Role of tourism in economy of Bali and Indonesia. Journal of Tourism and Hospitality Management, 5(2): 34-44. https://doi.org/10.15640/jthm.v5n2a4

[15] Spillane, J.C. (2004). Indonesian tourism: Economic strategy and culture engineering. Publisher: BP. Kanisius-Yogyakarta.

https://www.goodreads.com/book/show/1481563.Pariwi sata_Indonesia.

[16] Gromang, F. (2002). Tuntunan keselamatan dan keamanan wisatawan. Jakarta: Pradnya Paramita. https://onesearch.id/Record/IOS2863.JATEN00000000 0130662.

[17] Siswahto, E., Muryani, M. (2020). The impact of tourism on economic in North Sulawesi: Input-output analysis perspective. JDE (Journal of Developing Economies), 5(1). https://doi.org/10.20473/jde.v5i1.17924

[18] Mananeke, L. (2016). Tourism strategy development in North Sulawesi, Indonesia. The International Journal of Business \& Management, 4(10): 245-253.

[19] Kotler, P., Keller, K.L. (2015). Marketing Management, global edition. Pearson Education UK.

[20] Dinas Pariwisata dan Kebudayaan Provinsi Sulawesi Utara. (2019). Pembangunan Kunjungan Wisatawan di Sulawesi Utara. https://www.liputan6.com/lifestyle/read/4028740/menp ar-menilai-pembangunan-pariwisata-di-sulut-sangatpesat.

[21] Wiyata, A.S. (2015). Faktor-faktor yang mempengaruhi kunjungan wisata diberbagai objek wisata di kabupaten mojokerto. Swara Bhumi, 1(1). https://jurnalmahasiswa.unesa.ac.id/index.php/swarabhumi/article/view/10635.

[22] Sumayang, L. (2003). Dasar-dasar Manajemen Produksi dan Operasi. Jakarta: Salemba Empat. http://opac.ut.ac.id/detail-opac?id=18006.

[23] Pinontoan, R.R. (2013). Sikap dan budaya terhadap daya tarik objek wisata di kota manado. Jurnal EMBA: Jurnal Riset Ekonomi, Manajemen, Bisnis dan Akuntansi, 1(4). https://doi.org/10.35794/emba.v1i4.3403

[24] Agusra, D., Lussianda, E.O., Afriyeni, Y. (2019). Promotional strategies to increase tourist visits to agrotourism in Pekanbaru Raya, Riau Province. AKUNTABEL, $16(1)$ https://doi.org/10.29264/jakt.v16i1.5381

[25] Hasan, A. (2015). Tourism Marketing. Yogyakarta: CAPS.

[26] Suharto. (2016). Studi Tentang Kemanan dan Keselamatan Pengunjung Hubungannya dengan Citra Destinasi (Studi Kasus Gembira Loka Zoo). Jurnal Media Wisata, 14(1): 287-304. https://amptajurnal.ac.id/index.php/MWS/article/view/1 49.

[27] Khalik, W. (2014). Kajian Kenyamanan dan Keamanan Wisatawan Di Kawasan Pariwisata Kuta Lombok. JUMPA, 1(1): 23-42.

[28] Kővári, I., Zimányi, K. (2011). Safety and security in the age of global tourism. APSTRACT, 5(3-4): 59-61. https://doi.org/10.19041/APSTRACT/2011/3-4/10 